\title{
ANALYSIS OF FOREIGN SOURCES ON THE FORMATION OF ENVIRONMENTAL AWARENESS IN PRIMARY SCHOOL STUDENTS
}

\section{Bakhtiyor Kh. Kamolov}

Doctor Of Philosophy (Phd) In Geography, Lecturer Department Of Ecology, Namangan State University Uzbekistan

\author{
Saodat U. Sulaymonova
}

Researcher Department Of Theory And History Of Pedagogy, Namangan State University Uzbekistan

\section{ABSTRACT}

The formation of a positive attitude to environmental awareness in the individual, the study of the population's demand for environmental knowledge is one of the most important issues of the leading countries today. The theoretical analysis shows that the following aspects are a priority in the practice of leading foreign countries in the field: In developed countries such as the United States, Great Britain, France, Finland, Norway, Japan, the issue of environmental education for children from primary school age is considered. Education is an effective tool in the fight against poverty, saving lives and improving the quality of life. In countries south of South Asia and the Sahara, three out of four students fail to reach 5 th grade. The low level of quality and efficiency in schools, which are unable to meet the needs of many students who are not mastering in the primary school, is causing problems in the world of education. The article focuses on the systematic analysis and teaching methods of subjects taught in primary school in developed countries, and recommendations for the application of modern methodological approaches in the lower grades of secondary schools in the country.

KEYWORDS:- South Asia, Johannesburg-2002, Children's World, Mother Tongue, Teacher's Guide, Great Britain, Uzbekistan, Mother's School, Reading, Writing, Mathematics, Labor, Music,Physical education, The world around us, Drawing, Ethics, Foreign language, Children's World, modern technologies.

\section{INTRODUCTION}

World experience shows that the study of the education system in developed countries, the exchange of experience and the effective use of methods is a requirement of the times. Based on the effectiveness of the research conducted in the framework of this dissertation, it is necessary to review the qualification requirements for primary school and put into practice a new edition. At the UN Conference on Environment and Development in Rio de Janeiro in 1992, it was decided to preserve the environment and ensure a decent, comfortable life for the younger generation, and further development between the countries. The global forum "Johannesburg2002 " approved the program of development of the XXI century, defined as the program of action of all countries in the XXI century. This program is a document of world practice aimed at ensuring sustainable development, safe for the environment, taking into account the current needs and the interests of future generations [2; p. 5].

The formation of national policy and key areas of international cooperation is based on maintaining the country's environmental potential. Uzbekistan cooperates with the 
CURRENT RESEARCH JOURNAL OF PEDAGOGICS 2(11): 18-23, November

2021 DOI: https://doi.org/10.37547/pedagogics-crjp-02-11-07

ISSN 2767-3278

(C)2021 Master Journals

\section{Crossref do) 8 Google}

Accepted 25th November, 2021 \& Published 30 ${ }^{\text {th }}$ November, 2021

Commonwealth of Independent States on regional integration issues on the basis of bilateral agreements with individual CIS members (Russian Federation, Ukraine) and the Interstate Environmental Council, which is a subsidiary body of the CIS Executive Committee. The CIS Development Action Plan until 2025, prepared in 2000 and signed by the heads of state, provides for measures to protect the environment (environmental monitoring, environmental safety, a single system of classification and marking of industrial waste, etc.) [2; p.250 ].

Main part. World experience shows that the study of the education system in developed countries, the exchange of experience and the effective use of methods is a requirement of the times. Based on the effectiveness of the research conducted in the framework of this dissertation, it is necessary to review the qualification requirements for primary school and put into practice a new edition. At the UN Conference on Environment and Development in Rio de Janeiro in 1992, it was decided to preserve the environment and ensure a decent, comfortable life for the younger generation, and further development between the countries. The global forum "Johannesburg-2002" approved the program of development of the XXI century, defined as the program of action of all countries in the XXI century. This program is a document of world practice aimed at ensuring sustainable development, safe for the environment, taking into account the current needs and the interests of future generations.

Shortly after gaining independence, Uzbekistan became a member of the United Nations in 1992 and began cooperating with a number of its programs and specialized organizations, including the United Nations Environment Program (UNEP), the United Nations Development Program (UNDP), many more organizations, such as the United Nations
Educational, Scientific and Cultural Organization (UNESCO). The formation of national policy and key areas of international cooperation is based on maintaining the country's environmental potential. Uzbekistan cooperates with the Commonwealth of Independent States on regional integration issues on the basis of bilateral agreements with individual CIS members (Russian Federation, Ukraine) and the Interstate Environmental Council, which is a subsidiary body of the CIS Executive Committee. The CIS Development Action Plan until 2025, prepared in 2000 and signed by the heads of state, provides for measures to protect the environment (environmental monitoring, environmental safety, a single system of classification and marking of industrial waste, etc.)

In the field of environmental protection, Uzbekistan has participated in a bilateral agreement and started to create a special subregional structure of sustainable use of nature and environmental protection regulations. The Eurasian Economic Cooperation Report established in 2006 established a Standing Committee on Eurasian Economic Cooperation, Nature Management and Environmental Policy, proposed by the Parliament of the Republic of Uzbekistan, to hold an intergovernmental meeting of the Parliament. Bilateral cooperation can be seen in the following countries. Regional cooperation Uzbekistan has been a member of ESCAP since 1992. Uzbekistan cooperates with ESCAP mainly in the field of training, including the Japan-Korea International Cooperation Agency and regional training centers in India (GIS), China (waste), Malaysia and Thailand (environmental management). Uzbekistan is a member of the Regional Intergovernmental Organization for Social and Economic Development, the Economic Cooperation Organization (ECO), which includes the following ten countries: Azerbaijan, Poland, 
CURRENT RESEARCH JOURNAL OF PEDAGOGICS 2(11): 18-23, November

2021 DOI: https://doi.org/10.37547/pedagogics-crjp-02-11-07

ISSN 2767-3278

(C)2021 Master Journals

\section{Crossref dof 81 Google}

Accepted 25th November, 2021 \& Published 30 ${ }^{\text {th }}$ November, 2021

Afghanistan, Kazakhstan, Pakistan, Tajikistan, Turkmenistan, Turkey and Uzbekistan. ECO deals with issues of cooperation in the field of environmental protection in the field of energy, natural mineral resources and the environment. In the ECO ESKA-251 report, Uzbekistan also closely cooperates on the state of the environment and the use of natural resources [9; p.301]. According to the famous Czech educator J.A. Comenius, man is the most beautiful creature in nature. Man can learn everything by following nature. He expressed his important pedagogical ideas in his works "The Great Didactics", "Languages are the Open Door of Science", "Astronomy", "Mother's School", "Angel of Peace" [10; p. 132].

Comenius likened the duration of the delivery of a set of ideas to primary school students to four seasons that are repeated in nature: "Mother's School" is reminiscent of a beautiful spring covered with fragrant plants, buds and flowers; "Mother Tongue" school is like summer and some early ripening fruits; In the "gymnasium" he reaps a bountiful harvest in the fields, orchards and terraces, reminiscent of autumn, which is placed in the treasury of the mind; Comenius recommended that students aged 6-7 at the Mothers' School acquire the following knowledge and skills to form environmental awareness. According to him, students:

- count the names of water in nature, water cycle, globe, weather, precipitation in nature, rain, snow, wild and domestic animals, fruit trees, birds, etc.;

- knowledge of the difference between day and night and galaxies, the idea that the moon and sun rise and set every day;

- must know what a mountain, field, valley, rural river, city is, depending on the nature of the place where he lives.

Comenius explained every observed phenomenon in relation to nature. He gave an interesting title to the books that caught the attention of elementary school students and gave a full description of their content. He says the most beautiful thing available in the area is to sample from different views of the garden. In his other works, he highlighted the peculiarities and importance of nature in the education of general secondary school students.

I.G. Pestalotsi's ideas are still used in pedagogy [8; p. 92]. He has created works such as The Observation Alphabet, Instructional Teaching on Numbers, and The Swan Song. According to I.G. Pestalotsi, the upbringing of a child should be in harmony with nature. He followed this idea of J.A. Comenius, Jean-Jacques Rousseau. "If the movement of nature for the growth of human forces is not supported, these movements will slowly free people from emotional traits. Proper upbringing helps to cultivate them, that is, all human forces "[7, p. 88]. I. Pestalozzi promotes the following didactic rules that promote the mental development of children:

- Harmony of education with nature;

- Orientation from simple to complex;

- Adaptation to the child's strengths and abilities;

- Demonstration.

I.G. Pestalotstsi laid the foundation of a special methodology of primary education, substantiated the content of elementary education in natural sciences, the world around us, geography, local lore, and put into practice his recommendations on the integration of geography and medicine to enrich the child's language.

K.D. Ushinsky, the founder of Russian national pedagogy, wrote the works "Children's World", "Mother Tongue", "Teacher's Guide". Ushinsky left a lot of information about how to teach elementary school students. This was important 
CURRENT RESEARCH JOURNAL OF PEDAGOGICS 2(11): 18-23, November

2021 DOI: https://doi.org/10.37547/pedagogics-crjp-02-11-07

ISSN 2767-3278

(C)2021 Master Journals

Crossref dof 81 Google

Accepted 25th November, 2021 \& Published 30th November, 2021

as great news. He recommended, first and foremost, linking teaching to child labor. He studied the education in schools abroad and wrote his own works "Benefits of pedagogical literature", "Methods of primary education", "Mother's word" [6; p. 34].

A number of pedagogical scientists and specialists have conducted research on the introduction of nature to primary school students and proposed new methods for practical application.

In her book "Methods of acquainting children with nature" S.A. Veretenikova substantiated the method of acquainting children of each age group with nature according to the seasons.

A.G.Grigoryants, U.B.Gafurova's manual "Ecological education in children" gave valuable advice on the methods of ecological education, illustrating their ways with examples, as well as ways to cultivate simple research activities. Bringing up the next generation as a harmoniously developed person is one of the current issues [5; p. 101]. In this regard, it is important to introduce children to nature. In this sense, the structure of subjects taught in primary school in developed countries today has been studied (see Table 1.).

Table 1.

In primary classes in developed countries the structure of the subjects taught

\begin{tabular}{|c|c|c|c|c|}
\hline № & $\begin{array}{c}\text { Countries with } \\
\text { developed } \\
\text { education } \\
\text { systems } \\
\end{array}$ & $\begin{array}{c}\text { Age of } \\
\text { admission to } \\
\text { primary school }\end{array}$ & $\begin{array}{c}\text { The } \\
\text { composition } \\
\text { of primary } \\
\text { classes }\end{array}$ & Subjects that are tought \\
\hline 1. & USA & 5 years old & $1-5$ & $\begin{array}{l}\text { 1.Mathematics } \\
\text { 2. Reading } \\
\text { 3. Writing } \\
\text { 4.Special subject (increase of } \\
\text { spelling and vocabulary) } \\
\text { 5. Social science (history) } \\
\end{array}$ \\
\hline 2. & Russia & $\begin{array}{c}6 \text { or } 6.5 \text { years old } \\
\text { (twice a year) }\end{array}$ & $1-4$ & $\begin{array}{l}\text { 1.Reading } \\
\text { 2. Literate writing } \\
\text { 3.Mathematics } \\
\text { 4.Crafts } \\
\text { 5.Music } \\
\text { 6. Physical education } \\
\text { 7. Choreography } \\
\text { 8. Art }\end{array}$ \\
\hline 3. & South Korea & 6 years old & $1-6$ & $\begin{array}{l}\text { 1.Main customs and culture } \\
\text { 2. Korean and English } \\
\text { 3.Mathematics } \\
\text { 4. Social science }\end{array}$ \\
\hline 4. & China & 5 or 6 years old & $1-6$ & $\begin{array}{l}\text { 1. Chinese } \\
\text { 2.Mathematics }\end{array}$ \\
\hline
\end{tabular}


CURRENT RESEARCH JOURNAL OF PEDAGOGICS 2(11): 18-23, November

2021 DOI: https://doi.org/10.37547/pedagogics-crjp-02-11-07

ISSN 2767-3278

(C)2021 Master Journals

Crossref dof 81 Google

Accepted 25th November, 2021 \& Published 30 ${ }^{\text {th }}$ November, 2021

\begin{tabular}{|c|c|c|c|c|}
\hline & & & & $\begin{array}{l}\text { 3. Natural sciences } \\
\text { 4. Music } \\
\text { 5. Foreign language (English) } \\
\text { 6. Spiritual education } \\
\text { 7. Physical education }\end{array}$ \\
\hline 5. & Singapore & 6 years old & $1-6$ & $\begin{array}{l}\text { 1. Writing } \\
\text { 2. Reading } \\
\text { 3.Mathematics } \\
\text { 4. Chinese and English }\end{array}$ \\
\hline 6. & Uzbekistan & 7 years old & $1-4$ & $\begin{array}{l}\text { 1. Reading } \\
\text { 2. Writing } \\
\text { 3.Mathematics } \\
\text { 4.Labor } \\
\text { 5. Music } \\
\text { 6. Physical education } \\
\text { 7. The world around us } \\
\text { 8.Drawing } \\
\text { 9. Ethics } \\
\text { 10.Foreign language 11.Russian }\end{array}$ \\
\hline
\end{tabular}

Therefore, it is expedient to study the experience of the United States, the Russian Federation, the People's Republic of China, South Korea and Singapore, where the stages of development of education in the world are rapidly developing and improving, as an experiment in the stages of primary education.

Accordingly, it is expedient to establish a system of teaching students from an early age as a generalized science about the environmental problems caused by human activities and behavior, and what to pay attention to in order to prevent problems, to teach students on the basis of modern technologies.

\section{Conclusion}

If students are taught on the basis of different approaches in the teaching process, organized on the basis of modern pedagogical technologies, for example, on the basis of an animated approach, it is possible to increase students' perception of information. According to some sources, the first attempts to capture movement in the animated stories depict cave paintings from the Paleolithic period, in which animals depicted many legs wrapped around each other. In the east, a clay vessel was found in Sokta (Iran) and is estimated to be 5,000 years old. On the walls of the ship are 5 images of the donkey in motion. Pictures have also been found in Egypt (dating back to 2000 $\mathrm{BC}$ ). It was said that these drawings should be called the first examples of animation, but this is not entirely true because there was no equipment to show these drawings in motion. The first mention of such devices dates back to the second century AD - they invented it in China (around $180 \mathrm{BC}$, the inventor Ding Xuan). The device was invented in the 18th century and became the first popular device for playing animation. Using a set of rotating gaps, the phenacistcope shows the observer a sequence of images; there are slots on one disc and pictures on the other.

\section{REFERENCES}


CURRENT RESEARCH JOURNAL OF PEDAGOGICS 2(11): 18-23, November

2021 DOI: https://doi.org/10.37547/pedagogics-crjp-02-11-07

ISSN 2767-3278

(C)2021 Master Journals

Crossref dof 81 Google

Accepted 25th November, 2021 \& Published 30th November, 2021

1. Khasanboeva O., Jabborova H., Nodirova Z. Methods of acquaintance with nature. Textbook - Tashkent: Cholpon, 2013. - 27 p.

2. National Report. "On the state of the environment and the use of natural resources in the Republic of Uzbekistan. Tashkent: Chinor, 2008. - 250 p.

3. Tojiboeva R., Umarova M., Hamroqulova X. Reading book. Textbook (3rd grade). Tashkent: Uzbekistan, 2012. - 132 p.

4. Khasanboeva O., Ne'matova A., Turopova M. Odobnoma. Textbook for 3rd grade. Toshkent.Mehnat, 2004. - 41 p.

5. Bahromov A. Natural sciences. Textbook (3rd grade). - Tashkent: Cholpon, 2012. - 101 p.

6. Khasanov.A., Mirzaxo'jaev S. Secrets of saving in the family. A guide for high school students. - Tashkent: Teacher, 1999. - 34 p.

7. G'afforova T., Nurillaeva Sh., Haydarova 0. Native language and didactic games from reading for primary grades. Textbook Tashkent: Science, 2004. - 88 p.

8. 8.Tukhtaev A.S., Daminov A. Ecology and nature protection. Textbook - Tashkent: Teacher, 1994. - $92 \mathrm{p}$.

9. Sulaymonova S.U. Pedagogical aspects of formation of ecological literacy in students // Bulletin of NamSU. 2-son.-Namangan, 2019.B. -301.

10. Tojiboeva R., Umarova M., Hamroqulova $X$. Reading book. Textbook (3rd grade). Tashkent: Uzbekistan, 2012. - 132 p.

11. Dalibaevna, N. D. (2021). The Social Activity of Women Is One of the Important Factors in the Development of the Country. Eurasian Journal of Social Sciences, Philosophy and Culture.

12. Dalibaevna, N. D. (2021). GENDER EQUALITY IS ONE OF THE REQUIREMENTS OF A
DEVELOPED SOCIETY. CURRENT RESEARCH JOURNAL OF HISTORY (2767-472X), 2(06), 82-85. 